\title{
PERANAN GEREJA DALAM MENGHAMBAT LAJU PERTUMBUHAN PEMAKAI NARKOBA
}

\author{
Simon \\ Sekolah Tinggi Teologi Salatiga (STTS) \\ simon.petrus26@yahoo.com
}

\begin{abstract}
Indonesia is a country that is fertile ground for drug trafficking carried out by domestic dealers and drug dealers internationally. The rise of drugs today causes victims to die every day. President Jokowi came to state that Indonesia was on the verge of a "drug emergency", because every day 50 people died. If in just one year it could reach 18,000 people die each year. Seeing these facts, of course the government appealed through the National Narcotics Agency (BNN) that this should not be left unnoticed because it would have an increasingly bad impact. This research aims to give an idea to the churches that the spread of drugs and the number of users is alarming in the midst of this nation. The method that the author uses in writing this article uses a qualitative method with a literature study approach. The role that can be demonstrated by the church in drug prevention by preaching the dangers of drugs in the pulpits, partnering with BNN institutions as the frontline in eradicating drugs, conducting visits to rehabilitation sites and optimizing the role of families as supervisors.
\end{abstract}

Key words: User, Drugs, The role of the Church, Indonesian

\begin{abstract}
Abstrak
Indonesia merupakan salah satu negara yang menjadi lahan subur dalam peredaran narkoba yang dilakukan oleh para bandar dalam negeri maupun bandar narkoba secara internasional. Maraknya narkoba di masa kini menyebabkan adanya korban yang meninggal setiap hari. Presiden Jokowi pun sampai menyatakan bahwa Indonesia telah berada pada ambang "darurat narkoba," dikarenakan setiap harinya meninggal 50 orang. Bila dalam setahun saja dapat mencapai 18. 000 orang meninggal setiap tahunnya. Melihat fakta-fakta ini, tentunya pemerintah menghimbau melalui Badan Narkotika Nasional (BNN) mengemukan hal ini tidak boleh dibiarkan begitu saja karena akan semakin berdampak buruk. Penelitian ini bertujuan untuk memberikan gambaran kepada gereja-gereja bahwa penyebaran narkoba serta jumlah pemakainya sudah mengkuatirkan di tengah bangsa ini. Adapun metode yang penulis gunakan dalam penulisan artikel ini menggunakan metode kualitatif dengan pendekatan studi literatur. Peranan yang dapat ditunjukkan oleh gereja dalam pencegahan narkoba dengan mengkhotbahkan bahaya narkoba di mimbar-mimbar, bermitra dengan lembaga BNN sebagai garda terdepan pemberantas naskoba, mengadakan kunjungan ketempat rehabilitasi dan mengoptimalkan peran keluarga sebagai pengawas.
\end{abstract}

Kata-kata kunci: Pemakai, Narkoba, Peranan Gereja, Indonesia 


\section{Pendahuluan}

Indonesia menjadi salah satu negara sasaranperedaran narkoba yang dikendalikan jaringan internasional. Hasil deteksi Badan Narkotika Nasional (BNN) ada 72 jaringan internasionalyang menjalankan bisnis narkoba. ${ }^{1}$ Presiden Republik Indonesia Joko Widodo pun menyatakan bahwa Indonesia telah masuk kategori "darurat narkoba," hal ini dikarenakan setiap harinya penduduk Indonesia diperkirakan meninggal setiap harinya 50 orang. Jika diakumulasikan dalam setahun, maka ada sekitar 18.000 ribu orang meninggal dunia karena penggunaan narkoba. Angka itu belum termasuk 4,2 juta pengguna narkoba yang direhabilitasi dan 1,2 juta pengguna yang tidak dapat direhabilitasi. Data terbaru pada awal tahun 2019 seperti yang dikemukakan oleh Deputi Pemberantasan Badan Narkotika Nasional (DPBNN) RI, Irjen Pol Arman Depari menyatakanberdasarkan hasil survei prevalensi penyalahgunaan narkoba, jumlah pengguna narkoba di Indonesia mencapai lebih dari 4 juta orang. Dari angka prevalensinya, kita sudah sampai pada tahap mengkhawatirkan. Kurang lebih 4 sampai 4,5 juta. ${ }^{2}$

Banyaknya korban jiwa yang disebabkan oleh narkoba, ditenggarai karena merajalelanya para bandar sebagai pengedar dan pemasok kepada para pecandu. Oleh karena itu, presiden pun memerintahkan agar setiap bandar narkoba untuk diberikan hukuman yang setimpal agar para bandarnya jerah. Jokowi berkata seperti yang dimuat di Kompas "Sudah saya katakan, sudahlah tegasin saja. Terutama pengedar-pengedar narkoba asing yang masuk dan sedikit melawan. Sudah, langsung ditembak saja. Jangan diberi ampun, karena betul-betul kita ini ada pada posisi yang darurat di dalam urusan narkoba," lanjut dia. ${ }^{3}$

Badan Narkotika Nasional yang akan penulis singkat selanjutnya dengan BNN, melaporkan diperkirakan jumlah pengguna narkoba di Indonesia yang terpantau sudah mencapai enam juta jiwa. Akan tetapi angka ini belum dapat dikatakan secara pasti apakah hanya sebabas itu. Namun menurut BNN, para pecandu narkoba dalam skala nasional telah melebihi dari jumlah yang terpantau saat ini. Dengan jumlah di atas ini menandakan Indonesia sudah berada pada titik nadir dan darurat karena dampak dari narkoba. Guna memberantas narkoba dan bandarnya, maka BNN dari pusat tidak ragu menembak mati para penjahat narkoba, baik itu penyelundup, bandar, dan pengedar narkoba yang melarikan diri.

Pengaruh narkoba tidak hanya merajalela di kota-kota besar yang menjadi sasaran, akan tetapi narkoba juga telah merambah ke tingkat Kabupatan maupun desa. Merebaknya narkoba ditingkat kabupaten dan tingkat pedesaan, ditenggarai karena uang yang dihasilkan dari penjualan narkoba ini omsetnya sangatlah fantastis. Sebagaimana yang dikemukakan oleh BNN bahwa dalam waktu dekat, BNN akan mengungkap bisnis narkotika di atas Rp 150 triliun. Pihaknya sudah memiliki bukti. "Tinggal mencari waktu yang tepat," kata Buwas. Sejumlah bandar narkotika, masing-masing, bernilai puluhan triliunan rupiah juga tengah diselidiki BNN. Angka-angka itu menunjukkan berapa besarnya bisnis narkotika. ${ }^{4}$

${ }^{1}$ Uyat Suyatna, "Evaluasi Kebijakan Narkotika Pada 34 Provinsi Di Indonesia” Jurnal Ilmu-ilmu Sosial dan Humaniora, Vol. 20, No. 2, Juli 2018, 169.

2"pengguna-narkoba-tinggi-bnn-optimalkan-peran-keluarga-dan-masyarakata", https://regional.kompas.com (diakses )

3 "Jokowi saya sudah katakan tembak di tempat saja," https://nasional.kompas.com. Pidato Presiden Jokowi saat penutupan Rakernas Apeksi 2017 di Hotel Savana, Malang, Jawa Timur, Kamis 21-juli 2017 Pukul 17. 59 WIB.

${ }^{4}$ Budi Waseso adalah Kepala Badan Narkotika Nasional dan masa jabatannya sebagai kepala BNN, sudah berakhir pada tahun 2018. 
Kabupaten Pati di mana penulis tinggal yang terletak di Provinsi Jawa Tengah, dapat dijadikan contoh walau tidak terlalu tinggi mobilitas kehidupan layaknya seperti di Jakarta, namun permasalahan narkoba di Kabutan ini dapat dikatakan cukup terbilang tinggi. Tidak hanya para bandar dan masyarakan awam aja yang menjadi pemakai, namun oknum aparat kepolisian juga menjadi pemakai dari barang terlarang ini. Pada Februari 2017, surat kabar Muria Pati melansir bahwa"Oknum anggota Polres Pati yang ditangkap tangan oleh Kapolres AKBP Ari Wibowo saat menyalahgunakan narkoba beberapa waktu lalu, kini divonis hukuman 9 tahun kurungan penjara. Tak hanya itu, polisi tersebut juga dikenai denda sebesar Rp 1 miliar." 5

Peredaran narkoba di Pati bisa dikatakan cukup tinggi, karena berdasarkan muatan berita dari surat kabar online seperti Tribun Jateng menulis bahwa "Petugas Badan Narkotika Nasional Provinsi (BNNP) mengungkapkan keberadaan sindikat pengedar sabu yang menyasar Pati dan sekitarnya. Menurut Kepala BNNP Jateng Brigjen Tri Agus Heru Prasetyo, dari hasil pemeriksaan yang mereka lakukan, terdapat sabu-sabu yang akan diedarkan di wilayah pedesaan di pelosok Pati. Di antaranya Desa Kembang, Dukuhseti, Kedawung, dan Puncel. Seluruhnya terletak di Kecamatan Dukuhseti Kabupaten Pati. ${ }^{6}$ Terungkapnya sindikat narkoba yang dilakukan oleh BNNP di Kabupaten Pati, membuka mata khalayak masyarakat, bahwa narkoba memang bak seperti wabah yang sedang melanda semua lapisan masyarakat dan daerah-daerah di Indonesia termasuk di desa-desa.

Melihat fakta-fakta dari jumlah pengguna narkoba dalam skala nasional maupun di tingkat Kabupaten yang sangat memprihatinkan turut meresahkan keadaan di sekitar. Tentunya permasalahan narkoba ini tidaklah serta merta hanya BNN, aparat polisi dan instansi pemerintahan yang memeranginya. Akan tetapi peran masyarakat terlebih gereja harus hadir di sana untuk bahu membahu agar daya pengaruh narkoba tidak semakin luasserta tidak menambah jumlah pemakainya. Semua elemen masyarakat dibutuhkan perannya untuk penanganan dan memberi pertolongan bagi mereka yang kecanduan dari narkoba.

Di antara elemen-elemen masyarakat yang harus terlibat dalam pencegahan perluasan narkoba agar tidak bertambah jumlah pemakainya tentunya harus dimulai dari keluarga. Merupakan tanggung jawab orangtua dalam mendidik dan mengawasi karakter dan sikap anaknya masing-masing. ${ }^{7}$ Selain itu guru di sekolah dan pihak gereja perlu memberikan proses pendidikan yang berdasarkan Alkitab, berpusat pada Kristus dan bergantung pada Roh Kudus untuk perkembangan anak yang cerdas secara spiritual. ${ }^{8}$ Oleh sebab itu, gereja diharapkan untuk terlibat serta dibutuhkan aksi nyata dan kontribusi mengenai hal ini. Gereja tidak boleh diam bahkan menutup mata akan masalah-masalah sosial yang terjadi di sekitarnya, karena Allah memanggil gereja-Nya untuk menjadi terang kepada orang di sekitarnya. Sebagaimana yang dikemukakan oleh Zakaria: “Gereja bukan sekadar lembaga ritual keagamaan, melainkan alat yang dihadirkan Tuhan di dalam dunia untuk kesaksian Injil Kerajaan Allah mengenai kasih, keadilan dan damai sejahtera Allah

\footnotetext{
5"polisi pengedar sabu di Pati divonis 9 tahun dan denda 1 mliar" http:/ / www.koranmuria.com (diakses 5 September 2017).

6"inilah desa-desa di Pati yang jadi target sindikat narkoba pimpinan napi lapas sragen", http://jateng.tribunnews.com (diakses 1 September 2017).

7 Bernhardt Siburian, "Analisis Faktor-Faktor Penyebab Perceraian Berdasarkan Keputusan Pengadilan Negeri Balige Tahun 2017," Jurnal Ilmiah Religiosity Entity Humanity (JIREH) 1, no. 1 (2019): 31-39, https://ojs-jireh.org/index.php/jireh/article/view/5.

${ }^{8}$ Marsi B Rantesalu, "Guru Pendidikan Agama Kristen Sebagai Pelopor Revolusi Mental". AgriXiv, October 14, 2019. Last modified October 14, 2019. agrixiv.org/576qt.
} 
dalam Kristus. Karena itu gereja terpanggil untuk melakukan transformasi kehidupan manusia pribadi maupun masyarakat." ${ }^{9}$

Di antara isu permasalahan sosial, permasalahan narkoba perlu ditangani bahumembahu oleh semua kalangan, dan gereja harus ikut berpatner dengan negara untuk sebisa mungkin terlibat dalam menghambat laju pemakai narkoba. Bukankah gereja harus menyatakan sikap kepeduliannya kepada masyarakat di sekitar, karena Allah berfirman: "Tetapi kamulah bangsa yang terpilih, imamat yang rajani, bangsa yang kudus, umat kepunyaan Allah sendiri, supaya kamu memberitakan perbuatan-perbuatan yang besar dari Dia, yang telah memanggil kamu keluar dari kegelapan kepada terang-Nya yanga ajaib" ( 1 Ptr. 2:9).

Sebagaimana dikemukakan oleh Peter Wongso "Sebagai organisme hidup, gereja harus berkembang dan bertumbuh sebagaimana Kristus. ${ }^{10}$ Gereja yang hidup dan berkembang itu dapat diukur dari perannya dalam menunjukkan solidaritasnya terhadap permasalahan-permasalahan yang terjadi di sekitarnya. Frank Damazio pun mengungkapkan, setiap gereja lokal memiliki panggilan Ilahi, pemimpin-pemimpin yang telah ditetapkan dan tujuan yang telah ditentukan. Selain itu, tiap gereja lokal itu unik dan secara spesifik dipanggil untuk menggenapkan tujuan yang telah ditetapkan Allah bagi gereja lokal itu saja. ${ }^{11}$

Dengan gereja terlibat dan berperan agar laju pertumbuhan pemakai narkoba tidak bertambah itu merupakan wujud solidaritasnya. Bukankah perikemanusian dan perhatian serta keterlibatan kita dalam nasib sesama manusia adalah tuntunan agama Kristen yang berdasar pada perikemanusiaan Ilahi, pada perhatian serta keterlibatan Allah dalam nasib kita manusia." 12

\section{Tujuan Penulisan}

Tujuan dari penulisan artikel ini berangkat dari keprihatinan penulis melihat bahwa narkoba merusak hidup pemakainya dan dapat merusak tatanan lingkungan di sekitar. Sebagai contoh, jika kita tidak pemakai narkoba, namun lingkungan di sekitar kita marak beredar narkoba akan merugikan lingkungan di sekitar. Hal ini pun dikemukakan oleh Sumarlin Adams secara universal penyalahgunaan narkotika dapat mengancam dan merusak masa depan penggunanya, bahkan dapat menimbulkan kejahatan-kejahatan lainnya sebagai akibat sindroma ketergantungan terhadap zat kimia narkotika atau obatobatan terlarang. Sebab secara sosiologis mereka dapat mengganggu masyarakat dengan melakukan perbuatan-perbuatan abnormal atau kriminalitas di luar kesadaran mereka. ${ }^{13}$ Kemudian tujuan berikutnya dari penulisan artikel ini untuk mengajak dan mendorong jemaat dan para rohanian memikirkan dan berperan secara nyata, apa yang harus dilakukan oleh gereja terhadap permasalahan penyebaran narkoba dalam mencegah laju pertumbuhan pemakainya. Karena untuk mencegah laju peredaran narkoba tanggung jawab itu tidak hanya dibebankan kepada pemerintah maupun aparat penegak hukum saja. Tetapi, rohaniawan sebagai corong utama dalam menggerakkan organisasi gereja diperlukan tanggap dan kecekatannyaakanisu ini.

${ }^{9}$ Zakaria J. Ngelow, “Turut Membina Indonesia Sebagai Rumah Bersama - Peran Gereja Dalam Politik di Indonesia," Jurnal Jaffray 12, no. 2 (2014): 223.

${ }^{10}$ Peter Wongso, Theologia Pengembalaan (Malang: SAAT, 2007), 54.

${ }^{11}$ Frank Damazio, Strategic Church (Yogyakarta: ANDI, 216), 350.

${ }^{12}$ A. Heuken SJ, Ajaran Sosial Gereja (Jakarta Pusat: Yayasan Cipta Loka Ceraka, t.t.), 12.

${ }^{13}$ Sumarlin Adams, "Dampak Narkotika Pada Psikologi Dan

Kesehatan Masyarakat" Jurnal Health And Sport, Vol. 5, No. 2, 2012, 1-2. 


\section{Mengapa Gereja Harus Terlibat untuk Gerakan Anti Narkoba}

Mengapa gereja harus teribat dalam gerekan anti narkoba? Suatu pertanyaan yang perlu direnungkan oleh kita semua. Jawaban dari pertanyaan tersebut dapat dikemukakan bahwa keterlibatan gereja dalam gerakan anti narkoba bagian dari implementasi apa yang diungkapkan Tuhan untuk menjadi terang dan garam kepada mereka yang berada dalam kegelapan. Narkoba menjerat para pemaikanya dan itu bagian dari pusaran kegelapan, karena narkoba bak seperti belenggu yang sulit membuat pemakainya merdeka. Melihat hal ini, sudah sepatutnya gereja sebagai garda terdepan untuk hadir dalam gerakan anti narkoba sebelum para pemakainya makin bertambah banyak, serta gereja turut berkontribusi untuk membantu mereka agarkeluar dari lingkaran kelegelapan yaitu narkoba. Keterlibatan gereja dalam gerakan anti narkoba merupakan wujud kepedulian dalam menunjukkan belas kasihannya sebagaimana yang ditunjukkan oleh Kristus. Suardana mengemukakan: "Berbelaskasihan adalah penegasan hidup Yesus kepada mereka yang membutuhkan pertolongan-Nya. Dalam pelayanan-Nya, Yesus memakai sebuah pendekatan melalui perumpamaan. Perumpamaan orang Samaria yang murah hati menegaskan pengajaran Yesus tentang sikap yang dibangun oleh orang Kristen terhadap sesama." ${ }^{14}$

Gereja terlibat dalam pergerakan anti narkoba untuk menunjukkan bentuk solidaritas ke-sosialannya baik kepada lingkungan dan bangsa. Permasalah narkoba merupakan permasalahan yang berkaitan dengan hal-hal sosial, karena narkoba merupakan bagian dari permasalahan sosial, maka gereja sebagai lembaga rohani seyogianya juga berperan dalam ranah sosial, dan keterlibatan gereja harus hadir di sana. Ini merupakan bagian dari meneladani apa yang Yesus lakukan melalui keterlibatan-Nya pada isu-isu sosial. Makanya ketika Kristus dalam pelayanan-Nya selama di dunia, ia menyatakan solidaritas-Nya secara nyata dengan orang-orang yang mengalami berbagai masalah baik secara jasmani dan rohani. Ini juga ditunjukkan oleh jemaat mula-mula di Yerusalem, dengan menolong sesama anggota jemaat yang mengalami kekurangan. ${ }^{15}$

Gereja terlibat dalam gerakan narkoba juga bagian dari menjaga keutuhan keluargakeluarga Kristen yang berpotensi dirusak oleh pengaruh narkoba. Sudah bukan rahasia umum lagi bahwa banyak kasus yang menunjukkan akibat dari masalah narkoba menyebabkan banyak kerugian, baik materi maupun non materi. Banyak kejadian, seperti perceraian atau kesulitan lain bahkan kematian yang disebabkan oleh ketergantungan terhadap narkotika dan obat-obat terlarang. ${ }^{16}$

\section{Dasar Teologis Pembahasan dari Narkoba}

Secara literal, Alkitab memang tidak memuat atau menjelaskan mengenai narkoba. Namun secara implisit Tuhan melalui firman-Nya sangat melarang penggunaan obatobatan terlarang ini. Ayat-ayat ini merupakan bagian dari penjelasan akan larangan Tuhan dalam penggunaan narkoba. Efesus: 5:18 "Dan janganlah kamu "mabuk" oleh anggur, karena anggur menimbulkan hawa nafsu, tetapi hendaklah kamu penuh dengan Roh." 1 Korintus 5:11 "Tetapi yang kutuliskan kepada kamu ialah, supaya kamu jangan bergaul dengan orang, yang sekalipun menyebut dirinya saudara, adalah orang cabul, lapar uang,

${ }^{14}$ I Made Suardana, "Identitas Kristen dalamRealitas Hidup Berbelaskasihan: Memaknai Kisah Orang Samaria yang Murah Hati”, Jurnal Jaffray, Vol. 13, No. 1, April 2015, 125.

${ }^{15}$ Yunus Laukapitang, Daniel Ronda, “Aplikasi Ajaran Solidaritas Kristen Berdasarkan Alkitab Pada Gereja Kemah Injil Indonesia Kota Kupang Nusa Tenggara Timur" Jurnal Jafray, No. Vol. Ap, 152

${ }^{16}$ Isnayati Novita,Muhammad Noor,Dini Zulfiani, "Pencegahan dan Penanggulangan Narkoba Oleh Badan Narkotika Nasional Kota Samarinda”, Journal Administrasi Negara, Vol. 6, No. 4, 2018,8171 . 
penyembah berhala, pemfitnah, pemabuk ${ }^{\mathbf{1 7}}$ atau penipu; dengan orang yang demikian janganlah kamu sekali-kali makan bersama-sama." Jika melihat definisi dari narkoba menyebabkan pemakainya menjadi teler, maka hal ini sejalan apa yang dikemukakanoleh Alkitab bahwa mabuk atau teler bagian perbuatan yang dilarang oleh kebenaran firman Tuhan (Gal. 5:19;21).

Mabuk dalam bahasa Yunani menggunakan kata $\mu \varepsilon \theta \dot{v} \sigma \kappa \omega$ (methuskó) ${ }^{18}$ yang berarti bermabuk-mabukan atau minum sampai puas. Kecendruangan seseorang bila sudah mabuk anggur,pelakunya cenderung akan kehilangan kesadaran dalam berpikir maupun dalam berkata, karena itulah Paulus mengingatkan agar hendaknya jangan mabuk oleh anggur. Bila seseorang sudah mabuk, maka tingkat kesadarannya tentunya akan berkurang serta perlahan-lahan dapat merusak fungsi organ-organ tubuh. Bila dikaitkan dengan narkoba, pemakainya pun sering hilang kesadaran karena teler oleh karena pengaruh narkoba dan akan membuat kebugaran tubuh berkurang karena perlahan-lahan akan merusak sistim metabolisme tubuh.

Menyimak ayat-ayat di atas, dapat disimpulkan bahwa umat Tuhan yang melakukan perbuatan-perbuatan yang destruktif (merusak), termasuk yang di dalamnya adalah penyalahgunaan narkoba. Pemakain narkoba adalah tindakan yang merusak tubuh jasmani, karena secara tegas Allah berkata bahwa tubuh kita adalah bait-Nya. Firman-Nya berkata "Jika ada orang yang membinasakan bait Allah, maka Allah akan membinasakan dia. Sebab bait Allah adalah kudus dan bait Allah itu ialah kamu"(2. Kor. 3:17; 1 Kor. 6:19-20). Sebaliknya sebagai orang percaya, hendaknya menjaga dan merawat tubuh dan mempersembahkan untuk-Nya (Rm. 12:1), serta menyangkal setiap ajakan hawa nafsu, salah satunya pemakaian narkoba.

\section{Metode Penelitian}

Penelitian dapat diartikan sebagai upaya atau kegiatan yang bertujuan untuk mencari jawaban yang sebenar-benarnya terhadap suatu kenyataan atau realita yang dipikirkan atau dipermasalahkan, dan untuk memperoleh pengetahuan ilmiah tertentu yang berguna, baik bagi aspek keilmuan maupun bagi aspek guna laksana praktis, dengan menggunakan metode-metode tertentu menurut prosedur yang sistimatis. ${ }^{19}$ Untuk memperoleh data yang akurat dalam sebuah penelitian, maka diperlukan pelaksanaan metode penelitian yang tepat, agar rancangan dan metode dalam penelitian pada artikel ini mencapai tujuan penelitiannya. Dalam penulisan artikel ini, penulis menggunakan metode kualitatif dengan pendekatan studi literatur (Library research). Menurut Emzir penelitian kualitatif adalah suatu pendekatan apriori yang didasarkan pada asumsi filosofis (pendekatan naturalistis interpretif) pada penelitian kualitatif dan sumber-sumber informasi jamak dan pendekatan naratif yang tersedia bagi peneliti. ${ }^{20}$ Sedangkan menurut Sarosa penelitian kualitatif adalah penelitian yang mencoba memahami fenomena dalam setting dan konteks naturalnya (bukan di dalam laboratorium), yakni peneliti tidak berusaha memanifulasi fenomena yang ada. ${ }^{21}$ Oleh karena itu salah satu yang menjadi karakteristik

\footnotetext{
${ }^{17 K a t a}$ "mabuk" penulis tandai dengan bolt dan ini sejalan jika merujuk pada pengertian dari kata narkoba.

${ }^{18}$ Hasan Sutanto, Perjanjian Baru Interlinear Yunani-Indonesia \& Konkordansi Perjanjian Baru (Jakarta: BPK Gunung Mulia, 2003), 507.

${ }^{19}$ Maman Abdurahman, Sambas Ali Muhidin \& Ating Somantri, Dasar-Dasar Metode Statiska untuk Penelitian (Bandung: CV Pustaka Setia, 2011), 13.

20 Emzir, Metode Penelitian Kualitatif Analisis Data (Jakarta: PT Raja Frafindo Persada, 2016, cetakan ke 5), 1.

${ }^{21}$ Samiaji Sarosa, Penelitian Kualitatif Dasar-Dasar (Jakarta Barat: PT Indeks, 2017), 8.
} 
dari penelitian kualitatif itu data bersifat deskriptif. Maksudnya adalah data yang dikumpulkan lebih mengambil bentuk kata-kata atau gambar dari pada angka-angka. ${ }^{22}$

\section{Hasil dan Pembahasan}

\section{Dampak yang ditimbulkan dari pemakaian narkoba}

Narkoba mempunyai dampak negatif yang sangat luas, baik secara fisik, psikis, ekonomi, sosial, budaya, dan lain sebagainya. Apabila seseorang sudah kecanduan narkoba, maka ia akan menjadi ketergantungan serta akan sulit keluar dari lingkaran narkoba itu. Mereka yang pernah terjerat dalam pusaran narkoba, sering menghimbau agar jangan pernah coba-coba bersentuhan dengan barang terlarang ini. Aktor Roy Martin sebagai mantan pecandu narkoba berkata: "Satu hal yang pasti jangan pernah memakai atau mencoba narkoba. Jangan pernah mencoba sekalipun karena sekali kita coba, kita akan sangat amat sulit lepas dari itu," terangnya. Terlalu besar biayanya, terlalu besar yang kita bayar, bayar itu tidak hanya uang, tapi masa depan kita, kesempatan kerja kita. Terlalu banyak hal-hal positif yang kita buang ketika memakai narkoba." ${ }^{23}$

Selain kerusakan tubuh akan dialami oleh pemakai narkoba, kerusakan jiwani juga akan dialami mereka yang menggunakan narkoba. Adapun kerusakan jiwani disebutkan dalam buku UGM Mengajak Raih Prestas Tanpa Narkoba "Jiwa menjadi riang (euphoric) sesaat, lalu terpacu (stimulatde), namun kemudian menjadi tertekan (deppresed) sehingga menimbulkan rasa lesu." ${ }^{24}$ Kerusakan fisik, jiwa, yang akan lebih banyak ditimbulkan bagi pemakai narkoba, apapun hal itu hendaknya perlu diperhatikan. Oleh sebab itu dampak dari penyalahgunaan narkoba tidak hanya mengancam kelangsungan hidup dan masa depan penyalahgunanya saja, namun juga masa depan bangsa dan negara, tanpa membedakan strata sosial, ekonomi, usia maupun tingkat pendidikan. ${ }^{25}$

Melihat betapa bahayanya dampak narkoba yang ditimbulkan baik secara jasmani dan jiwani, tentunya menimbulkan kepedulian bagi semua elemen masyarakat terutama gereja. Narkoba pada dasarnya adalah racun. Kalau bukan racun, pasti sudah digunakan untuk pengobatan. ${ }^{26}$ Karena narkoba bagian dari racun maka tak jarang para para penggunanya menjadi mudah sakit, sulit berpikir, depresi, dan sakit lambung.

Peran gereja dalam gerakan anti narkoba dalam rangka pencegahan penyebaran luas dapat dilakukan dengan cara berikut:

1. Mengkhotbahkan bahaya narkoba dimimbar

Agama merupakan salah satu alat penangkalpenyalahgunaan narkotika (untuk semua golongan dan kalangan). Karena itu untuk semua umat khususnya umat Kristen yang taat beragama dandengan penuh disiplin melaksanakan ajaran agamadapat terhindar dari penyalahgunan narkotika. Kesadaran terhadap keberagamaanya, dapat menjagadiri/menghindarkan diri dari perbuatan yang dilarangagama (termasuk narkotika). ${ }^{27}$ Sebagai insan yang beragama, orang Kristen (gereja) hendaknya menyadari betul bahwa ia memiliki panggilan untuk terlibat dalam masalah-masalah sosial di

${ }^{22} \mathrm{Ibid}, \ldots \ldots . .3$.

23" mantan pengguna ini pesan Roy Marten tentang bahaya narkoba", https://www.fimela.com/news-entertainment/read/ (diakses 21 Juli 2017).

${ }^{24}$ Sri Suryawai, Derajad S. WidhYharto \& Koentjoro, UGM Mengajak Raih Prestasi Tanpa Narkoba (Yogyakarta: Gadjah Mada University Press, 2015), 147.

${ }^{25}$ Maudy Pritha Amanda, "Penyalahgunaan Narkoba Di Kalangan Remaja (Adolescent Substance Abuse)", Jurnal Penelitian \& PPM, Vol. 4, No. 2, Juli, 2017, 340.

${ }^{26}$ UGM Mengajak Raih Prestasi Tanpa Narkoba, 147.

27Tim Penyusun Marvel Ed Kawalu \& Tim BNN, Pandangan Agama Kristen Tentang Bahaya Penyalahgunaan Narkoba (Jakarta: Deputi Bidang Pencegahan, t.t.), 1. 
sekitarnya. Bukankah Alkitab menekankan agar mengusahakan kesejahteraan di mana gereja itu hadir (Yer. 29:7).

Pendeta, majelis, penatua maupun aktivis ketika mereka berkhotbah untuk tidak selalu materi hotbahnya bertumpu kepada masalah anugrah Allah, dosa, berkat, kasih, dan sebagainya. Sebaliknya mereka harus peka melihat keadaan sosial disekitarnya untuk mengumandangkan permasalahan sosial di antaranya mengenai bahaya narkoba. Para rohaniawan yang mengembalakan jemaat, ia harus memberi perhatian bahwa menyampaikan bahaya narkoba di mimbar, bagian dari partisipasi gereja dalam mencegah dan menghambat layu pertumbuhan pemakai narkoba khususnya bagi anggota jemaat. Kita perlu belajar dari apa yang Yesus perbuat, selain ia berfokus pada pemberitaan mengenai kerajaan Allah, Ia juga peka akan keadaan-keadaan sosial di mana saat Ia hadir. Sebagai contoh kepekaan Yesus pada masalah-masalah sosial, Ia mengkhotbahkan tentang adanya pengharapan bagi orang miskin (Luk. 4:18). Siapa yang dimaksud orang-orang miskin oleh Yesus, kepada siapa Ia katakan ia telah diurapi untuk menyampaikan kabar baik tentang Kerajaan dan kepada siapa Kerajaan itu diberikan. Yang dimaksud jelas sekali bukan hanya orang-orang miskin secara materi (sebab keselamatan yang menderita kekurangan). ${ }^{28}$ Tentunya kepada kedua kombinasi itu ditujukan.

Kepekaan Yesus tentang masalah sosial ialah mengenai perceraian ia ajarkan, tentang membayar pajak, keberatan Yesus karena komersialisasi Bait Allah oleh para pemuka Yahudi (Mat. 21:12-13). Singgih Mengemukakan: “Tuhan Yesus dan rasul-rasul pada gereja perdana bertindak secara langsung menangani orang-orang miskin. Menurut Yesus, Kerajaan Allah diperuntukkan bagi mereka yang miskin dan tidak berdaya. Allah adalah Allah yang adil, karena itu ia mendahulukan mereka yang miskin dan tidak berdaya. Hal ini di dalam literatur teologis disebut proferiantial option for the poor (pilihan untuk mendahulukan mereka yang miskin). Itu tidak berarti ketidakadilan, tetapi justru adil. $^{29}$

Apa yang diperbuat oleh Yesus tentunya menjadi teladan untuk para rohaniawan agar khotbah yang disampaikan tidak hanya berfokus pada masalah-masalah kerohanian saja, tetapi diperlukan kepekaan pada kondisi sosial yang terjadi di antarannya narkoba. Mimbar harus dioptimalkan seyoginya mungkin, selain menyampaikan pesan-pesan mengenai kerajaan Allah, mimbar dapat dijadikan oleh kaum rohanian untuk mensyiarkan mengenai bahaya penyalahgunaan narkoba. Bila Badan Narkotika Nasional (BNN) saja gencar mengkampanyekan bahaya narkoba baik melali media televisi, media cetak, dunia maya, dan menindak tegas para pengedar dan pemakai supaya peredaran tidak meluas serta semaksimal mungkin tidak bertambah jumlah pemakainya. Maka mimbar gereja pun ikut memperlihatkan perannya dalam pengkampanyean bahaya narkoba agar laju pertumbuhan pemakainya dapat berkurang dan tidak semakin bertambah.

Selama ini kecendrungan mimbar di gereja masih hanya bertumppu pada penyampaian khotbah hal-hal rohani dan program-program gereja disampaikan, dan amat minim mimbar dipergunakan untuk menyampaikan tentang permasalahan bahaya narkoba. Melalui peran gereja dalam mengumandangkan permasalahan narkoba di mimbar, setidaknya itu sudah menunjukkan peranannya mengenai permasalahanpermasalahan yang dihadapi oleh bangsa ini.

${ }^{28}$ John Scott, Isu-Isu Global Menentang Kepemimpinan Kristiani (Jakarta: Yayasan Komunikasi Bina Kasih, 1996), 315.

${ }^{29}$ Emanuel Gerrit Singgih, Iman \& Politik dalam era Reformasi di Indonesia (Jakarta: BPK Gunung Mulia, 2000), 48-49. 
2. Gereja bermitra dengan institusi Badan Narkotika Nasional (BNN)

Warga gereja perlu menyadari akan kekudusan hidup itu dalam dirinya, serta menyadari kehadirannya sebagai alat Tuhan untuk pelayanan dan pemeliharaan hidup sesamanya. Hal-hal yang akan merusak kekudusan hidup itu perlu dihindari, termasuk di dalamnya narkotika. ${ }^{30}$ Permasalah yang dihadapi oleh negara tentang narkoba ini adalah bagaian dari permasalahan gereja juga. Sebagai lembaga kerohanian yang keberadaannya diakui oleh negara, gereja mempunyai kewajiban untuk berkontribusi kepada negara. Bentuk kontribusi gereja kepada negara salah satunya keterlibatannya dalam mencegah laju pertumbuhan pemakai narkoba di negara ini. Oleh karena itu gereja seyogianya perlu bermitra dengan negera agar pemerintah terbantu melalui peran gereja. BNN memang sedang gencar-gencarnya untuk semaksimal mungkin menghambat laju peredaran dan pertumbuhan pemakai narkoba. Menurut Kepala BNN Komjen Pol Heru Winarko, "BNN terus berkoordinasi dan menjalin kerja sama dengan seluruh instansi pemerintah dan swasta, komunitas masyarakat, termasuk media massa, agar perkembangan narkoba bisa dicegah dan bersama-sama menumpas peredarannya. ${ }^{31}$

Keterlibatan gereja dalam pencegahan laju pertumbuhan pemakai narkoba dapat dilakukan dengan bermitra kepada BNN sebagai garda terdepan dalam memberantas laju penyebaran dan pertumbuhan pemakai narkoba. Apabila gereja bermitra dengan dengan $\mathrm{BNN}$, maka gereja dapat membuat program penyediaan tenaga-tenaga sukarela dalam membantu mereka yang sedang direhabilitasi. Agar hal ini terwujud, gereja membuat program rutinan dengan mengundang instansi BNN untuk mengadakan pelatihan maupun pengkaderan bagi anggota jemaat yang bersedia sebagai tenaga sukarelawan, untuk membantu mereka yang kecanduan narkoba. Keikutsertaan gereja mengenai hal ini menujukkan bagian misi kemanusiaan yang selaras dengan misi gereja untuk "Membawa yang berbeban berat kepada Yesus" (bdk. Mat, 11:28). Kalau kita melihat kondisi penyalahgunaan narkotika ini, memang mempunyai beban berat tidak saja pada dirinya karena kecanduan, tetapi juga penyakit yang menyertainya. Thiessen berkata "Sewaktu kita sedang bertugas di gereja serta merencanakan program-program gereja lokal, pertanyaan utama yang kita tanyakan ialah, Apakah yang menjadi misi gereja? Dengan kata lain, apakah seharusnya dilakukan oleh gereja? ${ }^{32}$

Sepanjang pengamatan penulis, amat minim gereja menunjukkan keterlibatannya dengan berpatner kepada BNN untuk bergandeng tangan dalam memerangi bahaya narkoba dan menekan laju pertumbuhannya. Padahal dengan gereja ikut berpatner dengan BNN, itu menunjukkan keseriusan serta kepedulian yang lebih akan masalahmasalah sosial serta itu bagian dari baktinya kepada nusa dan bangsa. Akan tetapi bila diperhatikan selama ini gereja kecendrungan mengeksklusifkan keberadaanya. Pendapat senada dikemukakan oleh Susanto "Gereja cenderung menjadi wilayah privat, dan menjauhkan diri dari dimensi sosial yang lebih luas. Isu-isu kemasyarakatan tidak dilihat sebagai ranah kerja gereja karena dianggap tidak berkaitan dengan kebutuhan spiritual manusia." ${ }^{33}$ Pelabelan gereja sebagai lembaga yang eksklusif berdampak pada BNN pun lebih cenderung menggandeng media televisi, aparat kepolisian, serta lembaga-lembaga

\footnotetext{
30" peranan gereja dalam penanggulangan penyalahgunaan dan peredaran narkotika", https://makassar.tribunnews.com (diakses 5 Juni 2019).

31“ bnn gencarkan sosialisasi bahaya narkoba", https:// nasional.sindonews.com (diakses Senin 1 Jui 2019).

${ }^{32}$ Henry C Thessen, Teologi Sistimatika (Malang: Gandum Mas, 2010), 509.

${ }^{33}$ Herry Susanto, "Gereja Sebagai Umat Allah dan Rekan Negara," Jurnal Jaffray 17, no. 1(2017): 36 .
} 
tempat rehabilitasi untuk kerja sama dalam pemberantasan narkoba. Peran gereja pun menjadi kurang menonjol dalam isu-isu masalah sosial ini. Sudah seharusnya setiap ada permasalahan-permasalahan yang berkaitan dengan ke-sosialan, gereja bermitra dengan lembaga apapun di antaranya BNN sebagai wujud publikasi akan Kristus kepada orang lain terutamaka kepada para pemakai narkoba.

3. Pendeta dan jemaat mengadakan kunjungan rutinan ketempat rehabilitasi

Pemerintah dengan segala usahanya telah berupaya semaksimal mungkin agar mereka yang kecanduan narkoba dapat ditangani dengan terlepas dari pengaruh narkoba. Adapun yang dilakukan oleh pemerintah melalui BNN dengan menyediakan berbagai fasilitas untuk rehabilitasi. Berdasarkan data yang diambil hingga 2011, telah ada 129 fasilitas kesehatan, dari level puskesmas, hingga rumah sakit jiwa, yang tersebar di 34 provinsi. $^{34}$ Walau pemerintah sudah menunjukkan upaya keseriusannya dalam penyebaran narkoba dan berusaha menekan laju pertumbuhan pemakai narkoba, tetapi keterlibatan gereja tetaplah harus hadir dalam permasalahan ini karena ini juga dapat dikatakan bagian dari pekabaran injil. Sebab pekabaran injil tidak melulu harus membicarakan tentang Yesus dan injil-Nya. Akan tetapi dengan gereja memperlihatkan kepekaannya pada masalah-masalah sosial disekitarnya, inidapat diibaratkan bagian dari penyebaran injil walau dalam interpretasi yang berbeda. Selama ini gereja masih tetap cenderung lebih sering mengadakan perkunjungan ke panti asuhan, penjara dan rumah sakit sebagai bagian dari program rutinan dalam mewartakan injil secara berbeda.

Akan tetapi untuk mengadakan kunjungan ketempat rehabilitasidi mana pecandu narkoba ada, gereja kurang memberi perhatian untuk hal ini. Mengunjungi tempattempat rahabilitasi narkoba sudah semestinyamenjadi agenda yang harus dilaksanakan sebagaimana rutinnya gereja mengunjungi rumah sakit dan panti asuhan maupun penjara. Dengan gereja mengunjungi mereka yang terjerumus sebagai pecandu narkoba, para pemakai akan merasa adanya dukungan moril yang diterimanya terutama dari lembaga gereja. Pendeta dan anggota jemaat yang mengadakan perkunjungan ketempat rehabilitasi, dapat melakukan kegiatan seperti "peribadahan singkat (berdoa, membaca alkitab dan sharing berita firman Tuhan yang dikondisikan dalam rangka pencegahan dan penanganan Narkotika); juga kegiatan pengenalan akan Narkotika dan aspeknya, serta kegiatan penyelesaian kasus dengan mengupayakan cara-cara penyelesaian." ${ }^{35}$ Dari sisi fasilitas pemerintah telah berupaya menyediakan apa yang dibutuhkan untuk menolong para pecandu narkoba agar tidak lagi bergantung perlu diapresiasi. Sebab, upaya itu akan berdampak pada penurunan jumlah pemakai narkoba. Akan tetapi dari sisi spiritualitas, gereja harus memperlihatkan perannya kepada para pecandu narkoba, dengan memberikan pelayanan-pelayanan kerohani di antaranya mengagendakan kunjungan ketempat-tempat rehabilitasi guna kebutuhan spiritualitas para pecandu narkoba. Memberikan layanan konseling kepada para pemakai narkoba, tentunya akan menolong untuk percepatan pemulihan yang kecanduan. Sebab, konseling merupakan salah satu tindakan yang efektif. Menurut Gibson sebagaimana dikutif oleh Maryatul "para pengguna, pecandu, yang merupakan korban dari penyalahgunaan narkoba, di dalam bimbingan dan konseling termasuk dalam kategori populasi yang spesifik. Para konselor bisa terlibat di dalam program pencegahan, intervensi, penanganan krisis dan

${ }^{34} J a l a n$ Panjang Pemulihan Pecandu Narkoba..., 164.

35Pandangan Agama Kristen Tentang Bahaya Penyalahgunaan Narkoba..., 8. 
pemulihan. ${ }^{36}$ Apabila kerohanian mereka bertumbuh, percepatan pemulihan akan terjadi dan ini menjadi keuntungan bagi negara dan bagi gereja, karenasemakin berkurang pemakai narkoba.

Gereja tidak boleh hanya bertumpu mengurusi hal-hal internalnya saja, tetapi ia harus menunjukkan perannya dan kepeduliannya kepada orang-orang yang sakit secara rohani dan jasmani. Sakit secara jasmani dapat dimaknai diantaranya mereka yang berada pada belenggu narkoba. Orang yang berada pada belenggu narkoba, maka gereja sudah sepatutnya memiliki tanggung jawabuntuk menolongnya. Stott menyatakan, "Kita tidak boleh lari dari tanggung jawab sosial kita: dengan telinga yang terbuka lebar, kita harus menyimak kepada suara Dia, yang memanggil umat-Nya dari setiap usia untuk pergi ke dalam dunia yang sesat dan kesepian (sebagaimana Ia sendiri telah lakukan), dengan tujuan hidup di dalamnya dan mengasihi, untuk bersaksi dan melayani, seperti Dia dan bagi Dia. Itulah yang disebut 'misi. Misi adalah respon manusiawi terhadap penugasan Ilahi. Misi adalah keseluruhan gaya hidup Kristiani, termasuk baik tanggung jawab pemberitaan injil maupun tanggung jawab sosial, dengan didominasi oleh keyakinan bahwa Kristus mengutus kita ke dalam dunia sebagaimana Sang Bapa telah mengutus Dia ke dalam dunia, dan bahwa karena itu kita harus pergi ke dalam dunia-untuk hidup dan bekerja bagi Dia. "37

Mengunjungi para pecandu narkoba ke tempat-tempat rahabilitasi itu bagian dari peran gereja menunjukkan kepeduliannya agar laju pertumbuhan pemakai narkoba dapat dicegah. Dengan gereja mengunjungi para pemakai narkoba, tentunya para pemakai menganggap mereka diperhatikan secara psikologis maupun secara rohani. Secara psikologis para pecandu dibina dan secara kerohanian dibekali dengan siramansiraman kerohanian menjadi pribadi yang berubah dan bertobat. Bila gereja memberi perhatian kepada para pecandu narkoba agar mereka terlepas, seyogianya gereja sedang sedang mengimplementasikan apa yang diucapkan Yesus. Yesus mengemukakan "ketika Aku lapar, kamu memberi Aku makan, ketika Aku haus, kamu memberi Aku minum, ketika Aku seorang asing, kamu memberi tumpangan. Ketika Aku lapar, kamu memberi Aku makan. Ketika Aku telanjang, kamu memberi aku pakaian, ketika Aku sakit, kamu melawat Aku, ketika Aku dipenjara, kamu mengunjungi Aku" (Mat. 25:3536).

4. Gereja mengoptimalkan peran keluarga dalam pengawasan penyebaran narkoba

Gereja adalah wadah persekutuan untuk orang percaya di dalam Tuhan Yesus. Melalui gereja Tuhan mempercayakan pelayanan dan pengajaran guna pengertian tentang hidup yang benar dan bermanfaat bagi-Nya dan bagi sesama. Gereja juga sebagai mercusuar dalam membentuk keluarga-keluarga Kristen yang sehat secara rohani dan jasmani. Sehat secara rohani dengan bertumbuh dalam iman melalui kesetiaan kepada Tuhan, sedangkan sehat secara jasmani, diantaranya tidak adanya anggota keluarga yang terlibat dalam pemakaian narkoba. Tidak bisa dipungkiri, sebagian besar para pemakai narkoba khususnya anak-anak muda mengakui bahwa ayah, ibu mereka tidak ada perannya dalam mengawasi setiap pergaulan mereka, sehingga menyebabkan mereka menjadi pemakai narkoba. Pendapat senada dikemukakan oleh Kawatu: "Keterlibatan ayah dan ibu dalam kesibukan duniawi, sering kali sampai melupakan pemeliharaan keluarga Kristen, hingga bukan lagi keluarga Kristen yang nyata, tetapi kekuasaan duniawi yang di kuasai oleh harta benda. Waktu

\footnotetext{
36Maryatul Kibtyah, "Pendekatan Bimbingan Dan KonselingBagi Korban Pengguna

Narkoba", Jurnal Ilmu Dakwah, Vol. 35, No.1, Januari, 2015, 63.

${ }^{37}$ Stott, Isu-Isu Global Menentang Kepemimpinan Kristen..., 3.
} 
yang ada hanya dipergunakan untuk mengejar harta duniawi, sehingga anak-anak menjadi terlantar, frustasi akhirnya menjadi liar dan narkoba menjadi sasaran mereka. Sementara yang lainnya menjadi kecewa karena kurang diperlihatkari lagi, apalagi dalam soal kerohanian." ${ }^{38}$

Keluarga merupakan hal yang penting dalam mengawasi penyebaran narkoba, karena mereka yang menggunakan narkoba sebagian besar beralasan bahwa keluarga tidak menjadi solusi atas permasalahannya. Belum lagi banyaknya keluarga sering berselisih. Kekerasan rumah tangga kini dianggap serius karena kian banyak terjadi. Banyak keluarga yang pecah, angka perceraian yang tinggi. ${ }^{39}$ Dengan kondisi keluarga seperti itu, mengakibatkan sebagian besar para pemakai narkoba melampiaskan ke narkoba untuk masalah yang dihadapinya. Disinilah keterlibatan gereja melalui keluarga harus terlihat agar laju pertumbuhan pemakai narkoba bisa dicegah melalui peran keluarga. Dengan gereja terlibat dalam pembentukan keluarga untuk hidup dengan prinsip-prinsip firman Tuhan, bukan tidak mungkin laju pertumbuhan pemakai narkoba berkurang berkat peran keluarga. Sebagaimana dikatakan oleh Sumarlin Adam, narkotika telah menyentuh lingkaran yang semakin dekat dengan kita semua. Teman dan saudara kita mulai terjerat oleh narkotika yang sering kali dapat mematikan. Sebagai makhluk Tuhan yang kian dewasa, seharusnya kita senantiasa berfikir jernih yang berdampak langsung pada keluarga dan kita harus memerangi kesia-siaan yang di akibatkan oleh narkotika. ${ }^{40}$

Agar keluarga-keluarga Kristen sesuai dengan apa yang dikehendaki oleh kebenaran firman Allah, maka gereja turut andil di dalamnya untuk menciptakan hal itu. Terciptanya keluarga Kristen yang menjalani hidupnya dengan prinsip-prinsip kebenaran firman Allah, akan menolong anggota keluarga, lingkungan dan masyarakat untuk menjaga diri agar tidak terjerumus dalam pemakain narkoba. Bila peran gereja terlihat dalam pembuntukan keluarga-keluarga yang takut Akan Tuhan, maka laju pertumbuhan pemakai narkoba akan berkurang karena keluarga-keluarga Kristen sehat secara rohani dan jasmani.

\section{Tujuan Pencegahan Narkoba yang Dilakukan Gereja di Generasi Pemuda}

Pemuda remaja sebagai generasi yang akan melanjutkan tongkat estafet kepemimpinan gereja dituntut untuk hidup benar dan tidak terlibat pada perbuatanperbuatan yang merusak badani dan moralitasnya. Agar hal itu tercipta, maka gereja berkewajiban melaksanakan perannya menjaga generasi kaum muda untuk hidup benar dengan mengajarkan nilai-nilai firman Allah agar tidak terlibat dalam penggunaan narkoba. Kehidupan yang benar itu di antaranya, tidak terlibat dalam penggunaan narkoba yang tentunya berpotensi merusak nilai-nilai rohani dan kerusakan badani. Tujuan dilakukannya pencegahan narkoba ini, karena pada masa kini para pemuda merupakan market utama para bandar narkoba. Hal itu kita bisa amati: "Penyalahgunaan narkotika dan obat-obatan terlarang di kalangan generasi muda dewasa ini kian meningkat. Maraknya penyimpangan perilaku generasi muda tersebut, dapat membahayakan keberlangsungan hidup bangsa ini di kemudian hari, sebab pemuda sebagai generasi yang diharapkan menjadi penerus bangsa, semakin hari semakin rapuh digerogoti zat-zat adiktif penghancur syaraf. Sehingga pemuda

38Pandangan Agama Kristen tentang Bahaya Penyalahgunaan Narkoba..., 7.

${ }^{39}$ David Canada, Spiritual Leadership (Malang: Gandum Mas, 2015), 69.

${ }^{40}$ Sumarlin Adam, "Dampak Narkotika Pada Psikologi Dan Kesehatan Masyarakat", 4-5. 
tersebut tidak dapat berpikir jernih. Akibatnya, generasi harapan bangsa yang tangguh dan cerdas hanya akan tinggal kenangan. ${ }^{41 "}$

Bila gereja ingin tetap eksis, maka pemuda remaja sebagai generasi penerus dalam melanjutkan tongkat estafet kepemimpinanya, gereja harus menjadi corong utama untuk memprotektif kehidupan para pemuda agar tidak dirusak oleh narkoba. Ini merupakan bagian dari panggilan Ilahi sekaligus agar menjaga adanya generasi yang berkesinambungan yang benar di hadapan Tuhan. Sebab, Alkitab memberikan contoh ketika angkatan Yosua beserta tua-tua Israel yang takut akan Tuhan meninggal, maka Alkitab menulis bahwa “bangkitlah generasi yang tidak mengenal Allah"(Hak. 2:10). Bangsa Israel gagal merawat tali rantai generasi yang berkenan kepada Tuhan, akibatnya berdampak pada munculnya generasi yang mendukakan hati Tuhan. Tujuan yang dilakukan gereja dalam pencegahan narkoba kepada kaum muda, agar tidak putusnya generasi yang berkenan kepada Tuhan. Sebab, bila para pemuda-pemuda Kristen lebih banyak terlibat dalam penggunaan narkoba, maka itu petaka bagi gereja karena masa depan gereja berpotensi menjadi semakin suram.

\section{Kesimpulan}

Narkoba adalah "wabah" bagi bangsa Indonesia, karena peredaran dan jumlah pemakai narkoba dari hari ke hari sudah sangat memprihatikan di tengah bangsa Indonesia. Merebaknya pengaruh buruk yang ditimbulkan oleh narkoba membuat Presiden Jokowi serta lembaga pemerintahan seperti Badan Narkotika Nasional bersepakat menghukum seberat-beratnya para bandar serta tidak mentolerir pemakainya. Semua elemen masyarakat baik pemerinathan termasuk gereja harus menunjukkan perannya untuk masalah hal ini. Gereja sebagai lembaga kerohanian yang mendidik masyakat untuk hidup benar, tentunya perannya harus diwujudkan dalam aksi nyata. Adapun peran gereja akan permasalahan narkoba ini, para pendeta perlu lebih vokal menyiarkan di mimbar-mimbar gereja dalam seruan akan bahaya narkoba. Tidak hanya mimbar, tetapi gereja juga menggandeng lembaga pemerintahan BNN dalam bermitra untuk membantu BNN dalam pemberantasan laju pertumbuhan pemakai narkoba.

Mengunjungi tempat rehabilitasi bagian dari bentuk dukungan moril kepada para pecandu narkoba, agar mereka bisa keluar dari pusaran barang terlarang ini agar sembuh dan lepas pengaruh ketergantunganya. Akan tetapi agar tidak sampai menjadi korban, maka peran keluarga diperlukan untuk menangani hal ini. Apabila laju pertumbuhan pemakai narkoba makin berkurang, tentunya ini merupakan kabar baik bagi negara dan juga bagi semua elemen masyarakat termasuk di dalamnya gereja. Keterlibatan gereja dalam pencegahan narkoba selain menunjukkan bentuk solidaritasnya, gereja juga mempersiapkan generasi yang sehat secara rohani dan badani guna melanjutkan tongkat estafet kepemimpinan gereja dalam memancarkan kasih Kristus.

\section{Rujukan}

Abdurahman, Maman, Sambas Ali Muhidin \& Ating Somantri. Dasar-Dasar Metode Statiska untuk Penelitian. Bandung: CV Pustaka Setia, 2011.

Adams, Sumarlin. "Dampak Narkotika Pada Psikologi Dan Kesehatan Masyarakat" Jurnal Health And Sport, Vol. 5, No. 2, (2012).

Alkitab: Jakarta: Lembaga Alkitab Indonesia, 2012.

Amanda, Maudy Pritha. "Penyalahgunaan Narkoba Di Kalangan Remaja (Adolescent Substance Abuse)", Jurnal Penelitian \& PPM, Vol. 4, No. 2, Juli, 2017.

${ }^{41}$ Maudy Pritha Amanda, Sahadi Humaedi, Meilanny Budiarti Santoso, "Penyalahgunaan Narkoba Di Kalangan Remaja(Adolescent Substance Abuse)," Jurnal Penelitian \& PPM, Vol. 4, No. 2, Juli, $2018,342$. 
Damazio, Frank. Strategic Church. Yogyakarta: ANDI, 2016.

Ed Kawalu, Marvel \& Tim BNN,Pandangan Agama Kristen Tentang Bahaya Penyalahgunaan Narkoba. Jakarta: Deputi Bidang Pencegahan, tt.

Eleanora, Fransiska Novita. "Bahaya Penyalahgunaan Narkoba Serta Usaha Pencegahan dan Penanggulangannya" Jurnal Hukum, Vol XXV, No. 1, (April 2011), 443-444, Universitas MPU Tantular Jakarta.

Emzir. Metode Penelitian Kualitatif Analisis Data. Jakarta: PT Raja Frafindo Persada, 2016.

Eunike, Sry Tyas, Suci, Asmin Fransiska \& Lamtiur Hasiana Tampubolon. Long And Winding RoadJalan Panjang Pemulihan Pecandu Narkoba. Jakarta: Kompas, 2015.

Heuken, A. SJ. Ajaran Sosial Gereja Menghadapi Masalah-Masalah Aktual. Jakarta Pusat: Yayasan Cipta Loka Caraka, 1982.

Kibtyah, Maryatul. "Pendekatan Bimbingan Dan Konseling Bagi Korban Pengguna Narkoba", Jurnal Ilmu Dakwah, Vol. 35, No. 1, Januari, 2015.

Laukapitang, Yunus Daniel Ronda, "Aplikasi Ajaran Solidaritas Kristen Berdasarkan Alkitab Pada Gereja Kemah Injil Indonesia Kota Kupang Nusa Tenggara Timur" Jurnal Jafray, No. 1, Vol. 11, (Jan, 2013).

Ngelow, Zakaria J. “Turut Membina Indonesia Sebagai Rumah Bersama-Peran Gereja Dalam Politik Di Indonesia," Jurnal Jaffray 12, no. 2, (2014).

Novita, Isnayati, Muhammad Noor, Dini Zulfiani, "Pencegahan Dan Penanggulangan Narkoba Oleh Badan Narkotika Nasional Kota Samarinda", Journal Administrasi Negara, Vol. 6, No. 4, (2018).

Rantesalu, Marsi B. "Guru Pendidikan Agama Kristen Sebagai Pelopor Revolusi Mental". AgriXiv, October 14, 2019. Last modified October 14, 2019. agrixiv.org/576qt.

Sarosa, Samiaji. Penelitian Kualitatif Dasar-Dasar. Jakarta Barat: PT Indeks, 2017.

Siburian, Bernhardt. "Analisis Faktor-Faktor Penyebab Perceraian Berdasarkan Keputusan Pengadilan Negeri Balige Tahun 2017." Jurnal Ilmiah Religiosity Entity Humanity (JIREH) 1, no. 1 (2019): 31-39. https://ojs-jireh.org/index.php/jireh/article/view/5.

Singgih, Emanuel Gerrit. Iman \& Politik dalam era Reformasi di Indonesia. Jakarta: BPK Gunung Mulia, 2000.

Stott. John. Isu-Isu Global Menentang Kepemimpinan Kristen. Jakarta: Yayasan Komunikasi Bina Kasih/OMF, 1996.

Suardana, I Made. “Identitas Kristen dalam Realitas Hidup Berbelaskasihan: Memaknai Kisah Orang Samaria yang Murah Hati", Jurnal Jaffray, Vol. 13, No. 1, April 2015.

Suryawai, Sri, Derajad S. WidhYharto Koentjoro. UGM Mengajak Raih Prestasi Tanpa Narkoba. Yogyakarta: Gadjah Mada University Press, 2015.

Susanto, Herry. "Gereja Sebagai Umat Allah dan Rekan Negara," Jurnal Jaffray 17, no. 1, (2017).

Sutanto, Hasan. Perjanjian Baru Interlinear Yunani-Indonesia \& Konkordansi Perjanjian Baru . Jakarta: BPK Gunung Mulia, 2003, 507.

Suyatna, Uyat. "Evaluasi Kebijakan Narkotika Pada 34 Provinsi Di Indonesia" Jurnal Ilmuilmu Sosial dan Humaniora, Vol. 20, No. 2, Juli (2018).

Thessen. Henry. C. Teologi Sistimatika. Malang: Gandum Mas, 2010.

Wongso, Peter. Theologia Pengembalaan. Malang: SAAT, 2007.

Webiste:

"Jokowi Saya Sudah Katakan Tembak Di Tempat Saja", https://nasional.kompas.com. (diakses Kamis 21-juli 2017).

"Pengguna Narkoba Tinggi-BNN Optimalkan Peran Keluarga dan Masyarakat", https://regional.kompas.com (diakses 10 Februari 2019). 
"Polisi Pengedar Sabu Di Pati Divonis 9 Tahun dan Denda 1 Mliar" http:/ / www.koranmuria.com (diakses 5 September 2017).

"Inilah Desa-Desa Di Pati Yang Jadi Target Sindikat Narkoba Pimpinan Napi Lapas Sragen", http:/ /jateng.tribunnews.com (diakses 1 September 2017).

"Mantan Pengguna Ini Pesan Roy Marten Tentang Bahaya Narkoba", https://www.fimela.com/news-entertainment/read/ (diakses 21 Juli 2017).

"Pengguna Narkoba Tinggi Bnn Optimalkan Peran Keluarga dan Masyarakat", https://regional.kompas.com (diakses 31 Agustus). 